\title{
ADSA Presidential Report
}

\section{James Linn}

University of Minnesota

I want to thank the membership for giving me the opportunity to be the 95th President of the American Dairy Science Association. It has been a great honor

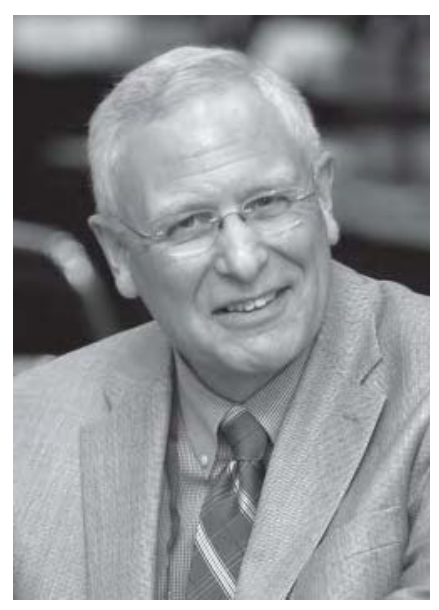

to lead a scientific society with the prestige and success of ADSA. The success and accomplishments of ADSA are directly attributed to the science contributions of our membership and the many hardworking volunteers who generously donate their time to serve on committees, the Board of Directors, and in many liaison positions in support of ADSA. Additionally, the support and facilitation of the outstanding professional and administrative staffs of ADSA and FASS enable ADSA to achieve its goals and provide products and services to the membership. Thank you to all for making 2010 another outstanding year for ADSA. Some special highlights and accomplishments in 2010 are reported below.

\section{Journal of Dairy Science ${ }^{\circledR}$}

The co-publishing contract with Elsevier began January 1,2010. The purpose of this contract is to effectively market JDS ${ }^{\circledR}$ around the world. All manuscript editorial and production responsibilities remain with FASS. Elsevier is a global marketer of several scientific publications and in partnering with them we hope to grow the readership of JDS and the membership of ADSA. The loss of several institutional subscribers around the globe was of particular concern and through Elsevier we expect to grow institutional subscribers in the coming years. The agreement with Elsevier also provides some financial loss protection for ADSA when open access of scientific publications occurs. The partnership with Elsevier also enabled ADSA to begin offering the most-cited research article awards. The inaugural awards recognizing authors of the most-cited articles in each of the journal's sections occurred at this year's awards program.
In Thompson Reuters' Agriculture, Dairy, and Animal Science category, the Impact Factor (2.497) for JDS was second highest of 55 journals for 2010 and remained ranked first by 5-year Impact Factor. In the Food Science and Technology category, JDS was ranked 18 out of 125 journals. The journal was also was ranked first by Eigenfactor (which removes self-citations). In 2010, we published 634 articles in 6,022 (science) pages in JDS.

\section{Communications and Other Publications}

The following initiatives were started this year and are examples of how we broaden the ADSA vision of science, education, and service to the dairy industry through partnership and collaborations.

Beginning with the 2011 volume of JDS, Hoard's en Espanol began publishing the interpretive summaries in Spanish, reaching 11,506 readers in 26 Spanish-speaking countries. This is a great partnership with a renowned industry publication to directly connect our research and scientific information to those who apply it.

The Dair-e-news, an electronic weekly newsletter, was started this year to provide members with timely news and science events related to the dairy industry along with ADSA information. The Dair-e-news is sent in partnership with the industry's leading animal nutrition publication, Feedstuffs magazine.

S-PAC ${ }^{\circledR}$ continues to grow, with more contributing conferences (39) and proceedings (382) and a record number of paid subscribers at the close of 2010 (all subscriber types $=489$ ). A change was made to the institutional subscription offering to make S-PAC more attractive to academic libraries. As a result, we now have institutions subscribing.

\section{Joint Annual Meeting}

The Joint Annual Meeting (JAM) was a huge success again this year. Attendance set a record for a twosociety (ADSA and ASAS) meeting. In total, 897 oral presentations, 1,341 posters, and 41 symposia allowed attendees to learn about the scientific discoveries of their fellow scientists. Dr. Kathy Woteki, Under Secretary for Agriculture Research, Education and Economics, Department of Agriculture, also visited JAM and 
observed, first-hand, the exchange of scientific information among attendees.

The JAM continues to be very successful but operates without an agreement or procedural documentation between the two principal societies involved, ADSA and ASAS. This past year a committee was appointed to develop an agreement and operation guidelines for the JAM, but was unable to complete it at the time of the Board of Directors meeting in July. The committee has been restructured and will continue with the goal of developing an agreement between the two societies for JAM.

\section{Membership}

Total individual memberships declined by two members this year. To grow our membership today and into the future, two strategic initiatives were delivered this year: The formation of the Western Student Affiliate Division (SAD), with a very successful inaugural meeting in the first week of March of this year, and the formation and launch of a separate Graduate Student Division (GSD). Students are our future, and they need to be a more prominent part of ADSA science and administration. The SAD President and the GSD President are members of the ADSA Board.

E-Membership is designed for those who have an interest in dairy science but may not have the time or budget to attend ADSA's annual meeting or to justify the cost of full membership in ADSA because of a different area of specialization. We now have 23 e-members, a number that will grow as this membership type begins to gain traction. Some new offerings and technology were deployed to enable the growth of ADSA e-membership.

The membership was profiled for the first time in 2010, providing ADSA with important, usable knowledge about who our members are and what their interests are. This newfound ability to segment the membership was put to quick use in asking members in academia to ask their respective librarians to subscribe to S-PAC.

In support of ADSA's goal of fostering international exchange, ADSA and the Ruminant Nutrition Laboratory (RNL) of the Institute of Animal Science (part of the Chinese Academy of Agricultural Sciences in the Ministry of Agriculture) sponsored the 2nd International Symposium on Dairy Cow Nutrition and Milk Quality on May 7-9, 2011, in Beijing, China. There were 680 attendees, with 60 from the RNL. Other registrants were from all areas of China and comprised universities (45\%), quality inspection (9\%), tech-extension (4\%), dairy companies (28\%), dairy farms (10\%), and speakers $(4 \%)$. Of the 30 speakers, 16 were ADSA members, of which 13 were from the United States. Three different sessions-Advances in Fundamental Research, Advances in Milk Quality and Safety, and Advances in New Technology and Products - were held twice, along with opening and closing sessions. An inaugural graduate student presentation contest was held with 70 submissions, 12 of which were selected for oral presentation. A special presentation on JDS was made to the graduate students. Winners of the graduate student competition were presented at the opening ceremony. Attendees were enthusiastic and engrossed in learning to further the relatively new dairy industry in China. ADSA looks forward to sponsoring a third symposium, in anticipation of increased participation throughout ADSA of Chinese dairy scientists.

\section{ADSA Foundation}

Discover Conferences continue to perform well with high conference evaluations. In May 2011, we used a new venue adjacent to O'Hare airport with great success. If you've never been to a Discover Conference, make 2012 the year to attend one and enjoy an exciting exchange of science and fellowship. Our thanks to Larry Miller and the excellent support, coordination, and meeting planning of Molly Kelley for making these conferences highly successful.

\section{Administration and Finances}

Financial performance for the Association continues to be strong. Revenue, mostly due to the journal's success, exceeded projections and expenses came in at budget. Preliminary operating profit came in at $271 \%$ of budget. The success of JDS and a good return on investments this past year were the major contributors to ADSA's profitable year.

Financial performance for the ADSA Foundation was also very good this past year. The total change in Foundation net assets was solidly positive in 2010, bringing Foundation net assets to all-time high. Successful Discover Conferences are the key driver of Foundation growth.

The ADSA Board reviewed the accomplishments of the strategic plan over the last five years (2006 five-year plan results) and the developing a new five-year strategic plan. Past President Gary Hartnell, who launched ADSA's first five-year strategic plan, did an excellent job of preparing the leadership and facilitating this critically important session in New Orleans. Six key areas were identified with leadership for each area assigned to the six directors. As part of each month's Board conference call, the activities and progress in meeting the goals of each strategic area are discussed. 
Finally, I want to thank again the many volunteers who serve ADSA so very well and in so many different capacities, with special thanks to my fellow Board members. Thank you for a great year and a great experience, too. Our accomplishments also come from an excellent ADSA executive director, Peter Studney, and supporting executive assistant, Cara Tharp. Larry Miller, Ken Olson, Molly Kelley, and Janet Brown are also deserving of special recognition for the outstanding work they do in supporting ADSA activities. We are extremely fortunate to partner with a very talented and dedicated FASS staff that provides excellent support for ADSA operations. Thank you to all the FASS staff for delivering the journal and the JAM, meeting our IT needs, and facilitating the many other products and services you deliver to our membership. 